\title{
CONCEPTS, CONCEPTIONS, AND PRINCIPLES OF JUSTICE
}

\author{
LOREN KING \\ Department of Political Science, Wilfrid Laurier University. Waterloo, Canada. ${ }^{1}$
}

\begin{abstract}
G.A. Cohen argues that Rawlsian constructivism mistakenly conflates principles of justice with optimal rules of regulation, a confusion that arises out of how Rawls has us think about justice. I use the concepts/conceptions distinction to argue that while citizens may reasonably disagree about the substance and demands of justice, some principled convergence may be possible: we can agree upon regulative principles consistent with justice, as each of us understands it. Rawlian constructivism helps us find that principled convergence, and this too is a conception of justice.
\end{abstract}

\section{Résumé}

G.A. Cohen pense que le constructivisme confond les principes de justice avec les règles de régulation optimale, une confusion qui découle de la manière dont Rawls pense la justice. En utilisant la distinction entre les concepts et les conceptions, j'affirme que, bien que les citoyens puissent

\footnotetext{
${ }^{1}$ The author is associate professor of political science at Wilfrid Laurier University, with teaching and research interests in theories of justice, decision and game theory, and moral issues in urban and global governance. I thank three reviewers for their very helpful suggestions, and am grateful to Jan Narveson, Colin Macleod, and fellow participants at the workshop in memory of G.A. Cohen hosted by the Society for Socialist Studies in May 2010, at Concordia University in Montreal. I had the great pleasure of meeting Jerry Cohen twice, and in those brief conversations I was humbled by his generosity and formidable acumen. Looking back on those fleeting exchanges, I have a sense of how extraordinary he must have been as a teacher and colleague, and how deeply he will be missed.
}

Je suis professeur de sciences politiques à l'Université Wilfrid Laurier, avec des intérêts dans les théories de la justice, la théorie du choix rationnel, et les questions morales dans la gouvernance urbaine et mondiale. Je remercie trois examinateurs pour leurs suggestions très utiles, et je suis reconnaissant à Jan Narveson, Colin Macleod, et les autres participants à l'atelier en mémoire de G.A. Cohen organisé par la Société d'études socialistes en mai 2010, à l'Université Concordia à Montréal. J'ai rencontré Jerry Cohen seulement deux fois, mais dans ces brèves conversations j'ai été ému par sa générosité et son perspicacité. En regardant en arrière sur ces échanges éphémères, j'imagine bien qu'il a dû être un extraordinaire professeur et collègue, et à quel point il va nous manquer.

Socialist Studies / Études socialistes: 


\begin{abstract}
raisonnablement contester la substance et les exigences de la justice, un accord de principe est possible: nous pouvons convenir de principes régulateurs compatibles avec la justice, comme chacun de nous la comprend. Le constructivisme Rawlsien nous aide à trouver cet accord de principe, et cela aussi est une conception de la justice.
\end{abstract}

\title{
Keywords
}

Rawls, G.A. Cohen, constructivism, justice, justification

\section{Mots Clés}

le constructivisme; G.A. Cohen; la justice; la justification; Rawls

G.A. Cohen's central complaint against Rawlsian constructivism is that it mistakenly conflates principles of justice with optimal rules of regulation, and this confusion arises out of the way Rawls has us reason about justice. I argue that this criticism is avoided on a different understanding of Rawls's aims.

Early in A Theory of Justice, Rawls notes the distinction between concepts and conceptions of justice, pointing out that while we might agree on the broad contours of a concept of justice, we can still reasonably disagree about the precise substance and particular demands of justice-that is, our favoured conception of justice. We can take this point further: reasonable people may disagree not only about conceptions of justice, but also over the concept of justice itself. Yet in both cases - divergent conceptions, and deeper disagreement about concepts - some principled convergence may be possible, where we can agree upon regulative principles broadly (or at least sufficiently) consistent with justice, as each of us understands it. Rawlian constructivism helps us find that principled convergence, and this too is a conception of justice: justice is fairness not only with respect to basic rights and distributional considerations, but also with respect to the relationships between our concepts and conceptions, on the one hand, and the authoritative principles of justice that bind us, on the other.

I will begin with a brief account of the central features of Rawlsian constructivism. I'll then detail Cohen's complaint, and conclude by showing how my interpretation, which emphasizes the concept/conception distinction in A Theory of Justice, rescues Rawlsian constructivism from at least this line of criticism.

\section{Rawlsian Constructivism}

Rawls insists that "a conception of justice cannot be deduced from self-evident premises or conditions on principles; instead, its justification is a matter of the mutual support of many considerations, of everything fitting together into one coherent view" $(1999,19)$. We begin with considered moral judgements made under favourable 
conditions. These judgements are not brute intuitions: they are provisional but stable conclusions we reach after reflection under conditions favourable to the sincere and sustained exercise of our rational capacities. Our conclusions reflect not just our own introspection, but our engagements with others, and especially with traditions of scientific inquiry and philosophical argument to which we have access-our reflective equilibrium is wide, not narrow. ${ }^{2}$ Some of these judgements are firm convictions "provisional fixed points which we presume any conception of justice must fit" (18) - but others are less certain, and several may conflict. Given this, we try to formalize our judgements into principles, and arguments for their interpretation and ordering, while keeping in mind whatever reliable insights we gain from background facts and theories. We then test our theory against our judgements, to see if the former does indeed clarify the latter, and provide principled resolution of conflicts among our judgements. ${ }^{3}$

The original position is Rawls's constructive procedure for generating principles for the basic structure of society, that we then judge against our considered judgements, working back and forth until we achieve reflective equilibrium. The salient features of this procedure - the circumstances of justice, rational and reasonable parties who take one another to be free moral equals, and the veil of ignorance - are also subject to the method of reflective equilibrium: we reflect on what constraints are most reasonable to impose on arguments for and against principles for free moral equals who seek fair terms of social cooperation. Reflective equilibrium thus does considerable work in Rawls's account: it is critical both to settling on principles that reflect and organize our considered judgments, and to defining the features of a procedure that constructs those principles. ${ }^{4}$

Rawlsian constructivism consists, then, of three interrelated and complex features: (1) the idea of considered judgements; (2) a constructive procedure for generating principles that interpret and order these judgements; and (3) a process of reflective equilibrium applied to (i) our considered judgements, and both (ii) the elements of the constructive procedure, and (iii) the principles generated by that procedure. The original

2 This way of interpreting considered judgements as intimately historical and public is strongly suggested in Theory $(\$ \$ 4,9)$ and especially Justice as Fairness ( $\$ \$ 9-10)$, but my formulation is based on Daniels (1973), especially his discussion of independent background theories that inform and constrain the more narrow process of bringing our principles and arguments in line with our most robust considered moral judgements.

3 A critical concern with this understanding of reflective equilibrium and coherentist justification is circularity: how can judgements and principles justify themselves? (for instance, see Haslett 1987). And if wide reflective equilibrium invokes background theories (about the natural world, human evolution and psychology, economic processes) as either inputs or constraints as we seek coherence between judgements and principles, then why isn't that background sufficient for grounding our justifications? Why appeal to coherence, rather than correct foundations? There are plausible (but not unassailable) answers to these questions, but I only note the broad contours of this debate to distinguish Cohen's concern with Rawlsian constructivism, which is not a variation on the circularity objection. 
position, for Rawls, models our considered judgements about fair terms of social cooperation among free moral equals and the "appropriate restrictions on reasons" that parties so understood may offer to one another in support of particular principles (Rawls $2001,17)$. The principles that emerge from this procedure in turn clarify and organize our considered judgements about morality and justice.

\section{Against Constructivism}

Cohen thinks the entire constructivist exercise is predicated on a mistake. Principles of justice - whatever they are - do not emerge from a constructive procedure. Rather, they are fundamental; they "represent our convictions. They are not things we decide to have and consequently work to install or instill or maintain" (Cohen 2008, 277). In contrast, "we create, or adopt, rules of regulation, to order our affairs: we adopt them in the light of what we expect the effect of adopting them to be" (276). Rawls presents reflective equilibrium as a model of moral justification, but Cohen insists that "it is our principled convictions that justify what we do, and that includes the doing that is adopting rules of regulation" (277).

Cohen allows that we can still ask properly philosophical (or at least, normativetheoretical) questions about rules of regulation: we can ask what they ought to be. The question of what justice is, however, does not - and cannot - take that form:

The question "what is justice?" is a philosophical question, and there is no coherent question of the form "What ought justice, or the principles of justice, to be?" the incoherence of that question reflects the status of justice as something that transcends rules of regulation (Cohen 2008, 277).

The problem, then, with constructivism as Rawls deploys it is not merely that he courts (bad, not harmless) circularity, or that he must smuggle in foundational claims to support a coherentist account of justification. The problem, Cohen suggests, is much deeper:

According to constructivism, fundamental principles of justice are derived from judgements (that do not themselves reflect principles of justice) about the right procedure for generating principles of justice, together with facts of human nature and human society $(2008,280)$.

Constructivists are muddled, Cohen believes, on several related points: they inappropriately apply general facts in constructing principles that are properly 
understood as fact-insensitive and unconstructed; in doing so they confuse general principles of regulation with principles of justice, and they "miscast applied principles of justice in the role of fundamental ones" (280). Furthermore, at least part of this confusion arises from the very epistemic procedure they privilege:

however the different versions of constructivist theories of social justice differ, whether in the nature of the selection procedure they mandate or in the principles that are the output of that procedure, they all assign to principles of justice the same role. That role is determined by the fact that constructivism's legislators are asked to elect principles that will regulate their common life (283).

That, Cohen suggests, is exactly the wrong question to be asking about justice.

\section{Concepts, Conceptions, and Constructivism}

I will not engage directly with the full scope and force of Cohen's argument supporting these claims. Instead, I want to see if the claims themselves still cohere as a critical thesis if we take the task and subject of Rawlsian constructivism to be more subtle than what Cohen (not unreasonably) supposes-that is, straightforwardly identifying principles of justice.

This will seem a strange strategy indeed, given that Rawls seems obviously to think of reflective equilibrium and the device of the original position as together a way of generating his favoured principles of justice. I think, however, that what Rawls says about concepts and conceptions of justice suggests a different task for reflective equilibrium and the original position as a constructive procedure. My favoured reading makes better sense of the direction Rawls took in later work, attending to the problem of public justification given the fact of reasonable disagreement.

Early in Theory, after describing "a public conception of justice as constituting the fundamental charter of a well-ordered human association" (1999, 5), Rawls offers the following distinction:

Existing societies are of course seldom well-ordered in this sense, for what is just and unjust is usually in dispute. Men disagree about which principles should define the basic terms of their association. Yet we may still say, despite this disagreement, that they each have a conception of justice. That is, they understand the need for, and they are prepared to affirm, a characteristic set of principles for assigning basic rights and duties and for determining what they take to be the 
proper distribution of the benefits and burdens of social cooperation. Thus it seems natural to think of the concept of justice as distinct from the various conceptions of justice and as being specified by the role which these different sets of principles, these different conceptions, have in common $(1999,5)$.

Now, we might think that Cohen's charge applies with full force here. Rawls, after all, seems to be thinking of the concept of justice, and the various conceptions of that concept, as primarily regulative. They establish "a fundamental charter" and assign "basic rights and duties" and determine "the benefits and burdens of social cooperation." These are principles of regulation, not of justice. Most damning is the specification condition Rawls asserts: that the concept of justice is given by convergent elements of differing conceptions. Since the conceptions are assumed to be regulative in Cohen's sense, then we can expect the set of shared elements to be regulative as well, so Rawls is still mistaken about the concept of justice, confusing it with optimal terms of regulation.

This is too quick, however. Rawls then goes on to describe the concept of justice as "a proper balance between competing claims" distinct from the conceptions that yield principles "for identifying the relevant considerations which determine this balance" $(1999,9)$. This, then, is what justice is, for Rawls.

To be sure, Rawls then in the same breath claims that the concept of justice is defined "by the role of its principles in assigning rights and duties and in defining the appropriate division of social advantages. A conception of justice is an interpretation of this role" (9). That may well be $a$ defining role, but we need not read Rawls here as simply equating justice with that (regulative) role. That is, we needn't read Rawls as giving merely regulative content to the concept of justice. Rather, he also defines the concept of justice in terms of a role that Cohen readily allows: shaping regulative principles in accord with whatever agreement is possible about what justice is and what it demands of us.

I think this is the best way to understand the tasks of reflective equilibrium and the original position in Rawls's account of justice as fairness. Wide reflective equilibrium gives us (inter alia) conceptions of the concept of justice. It may even yield divergent understandings of the concept itself. The original position then generates regulative principles consistent with convergent elements of both conceptions and concepts of justice-points of convergence the successful identification of which is also an important task of the device of the original position.

\section{Recovering Rawlsian Constructivism}

Cohen faults Rawls for failing to respect a vital definitional distinction between fundamental justice and optimal regulation. I think that Rawlsian constructivism 
proceeds from the implicit assumption that Cohen's distinction cannot be expected to settle the question of what justice is and what it demands by way of regulative principles. There are, of course, several reasonable understandings of what justice is. The primary task of Rawlsian constructivism, on my reading, is to find some space of convergence among these competing conceptions, even when they are conceptions of distinct concepts of justice; and then to ask what regulative implications follow from the substance of that convergence.

Cohen thinks that we need to be clear about justice, and then turn to questions of regulation, recognizing too that there are other virtues besides justice that our regulative principles may need to reflect $(2008,286)$. The error of Rawlsian and any other constructivism, on Cohen's view, lies in favouring an epistemic procedure that cannot discover fundamental principles of justice, or any other fundamental values. But I think Rawlsian constructivism, especially as it evolves through Political Liberalism (2005) and into Justice as Fairness (2001), does discover things about justice, as well as constructing regulative principles in accord with these discoveries. The device of the original position helps us find optimal principles of regulation consistent with a variety of conceptions of justice that interpret the concept of justice chiefly in terms of regulative consequences for a society characterized by reasonable moral pluralism. The original position discovers points of convergence among these conceptions-convergence that hopefully reflects some agreement on what justice is, which is one way to understand why Rawls quickly and decisively rejects a mere modus vivendi, and worries about stability "for the right reasons" (Rawls 2005, xxxvii). It isn't that the device of the original position has us asking the wrong questions to get at justice. Rather, Rawlsian constructivism assumes that (1) our considered judgements in reflective equilibrium are (inter alia) about the concept of justice and our favoured conception of that concept; and (2) we have distinctive and plausible supporting judgements about the ways in which regulative principles fall out of that concept and our favoured conception.

So contra Cohen, Rawls does have an answer to the question: what is justice? Justice is fairness. Fairness with respect to matters of regulation, certainly; but also fairness with respect to how we arrive at mutually acceptable regulative principles consistent with our concept and favoured conceptions of justice. Rawls supposes that most reasonable people, after due reflection under favourable conditions, will often agree roughly on what justice is (the concept of justice) while also affirming divergent interpretations (conceptions) of justice. Sometimes, of course, these same reasonable people will even disagree about the very concept of justice. Rawls's theory, as it evolved from Theory through Political Liberalism and later work, took seriously the likelihood of reasonable disagreement over both conceptions and concepts of justice, but hoped that we might nonetheless find principled ways to live together with a shared political conception of justice. 
Rawlsian constructivism is importantly a process of ensuring that shared regulative principles are, to the greatest extent possible, consistent with our considered judgements about what justice is. If those judgements are formed against a backdrop of sustained reflection under favourable conditions, then the complaint that constructivists confuse regulative principles with principles of justice rather misses the point. We, each of us, may well know what justice is. What we need to determine is how to proceed when we disagree among ourselves (and occasionally with ourselves!) about justice - what it demands, and sometimes even what it is - yet still desire to live together as free moral equals, according to shared regulative principles consistent with justice, as each of us understands it. Rawlsian constructivism strives to give us an answer to that question: what is justice for free moral equals who reasonably disagree about what justice is and what it demands? The resulting political conception is of justice as fairness.

\section{Concluding Thoughts}

There are, to be sure, cogent arguments against constructivism in ethics, and Cohen's is not the only plausible complaint against Rawlsian constructivism in particular. These are subtle and important debates, and while I have my own views on several of these disputes, my aims here are modest. I am not defending constructivism for ethical justification, nor do I hope to persuade any and all critics that Rawlsian constructivism is the best approach on offer. I only mean to defend a decidedly Rawlsian constructivism against Cohen's specific charge that Rawls and other constructivists ask the wrong question about justice. There is a plausible way to understand what Rawls is up to that is faithful to the spirit (if not always the precise letter) of A Theory of Justice; this interpretation makes a good deal of sense in light of themes in Rawls's later work, and avoids the force of Cohen's complaint. I thus conclude that, on a plausible reorientation of Rawls's arguments about the aims and substance of reflective equilibrium, on the one hand, and the workings of the original position, on the other, the concerns Cohen raises about constructivism are rather less troubling than they might at first seem.

\section{References}

Cohen, G.A.. 2008. Rescuing Justice and Equality. Cambridge, MA: Harvard University Press.

Daniels, Norman. 1973. "Wide Reflective Equilibrium and Theory Acceptance in Ethics." Journal of Philosophy 76, 5 (May): 256-282. 
Haslett, D.W. 1987. "What is Wrong with Reflective Equilibria?" Philosophical Quarterly 37, 148 (July): 305-311.

Rawls, John. 1999. A Theory of Justice. Revised Edition. Cambridge, MA: Belknap Harvard, 1971.

----. 2001. Justice as Fairness: a Restatement. Cambridge, MA: Belknap Harvard.

----. 2005. Political Liberalism. Expanded Edition. New York: Columbia University Press, 1993.

Scanlon, TM. 2003. "Rawls on Justification" in Samuel Freeman, ed. The Cambridge Companion to Rawls (Cambridge: Cambridge University Press). 